\title{
Productivity and Nutrient Content of Wheat (Triticum aestivum L.) as Influenced by Sowing Temperatures and Bio-regulators
}

\author{
Hansa Lakhran*, O.P. Sharma, Rohitash Bajiya and Meena Choudhary \\ Department of Agronomy, S.K.N. College of Agriculture, S.K.N. Agriculture University, \\ Jobner, Jaipur, Rajasthan, India \\ *Corresponding author
}

\section{A B S T R A C T}

\begin{tabular}{l} 
Ke y w o r d s \\
$\begin{array}{l}\text { Bio-regulators, } \\
\text { Nutrient content, } \\
\text { Sowing } \\
\text { temperature, Wheat, } \\
\text { Yield }\end{array}$ \\
\hline Article Info \\
$\begin{array}{l}\text { Accepted: } \\
\text { 20 September } 2020 \\
\text { Available Online: } \\
\text { 10 October } 2020\end{array}$ \\
\hline
\end{tabular}

\section{Introduction}

Wheat (Triticum aestivum L.) is one of the chief sources of diet by providing half of the dietary protein and more than half of the calories to the rising population of India. As a consequence, scientists are always focusing to produce higher yields to feed the nation (Khan et al., 2015). Wheat is grown in India on 33.61 Mha and produces of $106.21 \mathrm{mt}$ with national average yield of $3160 \mathrm{~kg} / \mathrm{ha}$ during 2019-20 (Anonymous, 2020a). In Rajasthan, the production reached the level $12.19 \mathrm{~m} \mathrm{t}$ with productivity of $3676 \mathrm{~kg} / \mathrm{ha}$ and acreage
A field experiment was carried out during rabi seasons of 2016-17 and 2017-18 at Agronomy Farm, S.K.N. Agriculture University, Jobner, Jaipur, Rajasthan, to obtain a suitable combination of sowing at different thermal regimes and foliar sprays of bio-regulators. The experiment was conducted in a split-plot design with four replications. The main plot treatments comprised three sowings, viz. $22{ }^{\circ} \mathrm{C}$, $20^{\circ} \mathrm{C}$ and $18{ }^{\circ} \mathrm{C}$ and subplots consisted of eight treatments of bio-regulators, viz. control, water spray, SA @ 100 ppm, SA @ 200 ppm, TSA @ 100 ppm, TSA @ 200 ppm, TGA @ 100 ppm and TGA @ 200 ppm. Crop sown at $20^{\circ} \mathrm{C}$ resulted in significantly highest yield and nutrient content over $22^{\circ} \mathrm{C}$ and $18{ }^{\circ} \mathrm{C}$. Among bioregulators, an application of salicylic acid @ 200 ppm registered significantly highest yield and nutrient content in grain and straw of wheat, thus, hold a great promise in wheat production under heat stress. 
Under the late sowing of wheat, applied inputs are not efficiently utilized which resulted into the yield declined by one per cent every day (Khan et al., 2010). Consequently, all the growth stages, such as seed emergence, tillering, flowering, and grain filling, are negatively affected by the shortened crop growth period. A rise in temperature leads to leaf senescence by reducing the optimum growth period resulting in a low photosynthetic rate (Sattar et al., 2010).

Bio-regulators (salicylic acid, thio salicylic acid and thio glycolic acid) regulate physical and physiological activities of the plants under adverse conditions (Agarwal et al., 2017). Salicylic acid is an important signaling molecule naturally occurs in plants as hormone and aids to tolerance against environmental stresses such as salinity, chilling, drought, heat heavy metal toxicity stress (Singh et al., 2020). The plant photosynthetic effectiveness and canopy photosynthesis are increased by the spray of thio salicylic acid and TGA due to presence of $\mathrm{S}-\mathrm{H}$ group as an integral constituent of these thiols (Shivran et al., 2019). They improve photosynthetically leaf surface area during vegetative phase in cereals by delaying senescence. Application of bio-regulators also increases the uptake and content of nutrients $(\mathrm{N}, \mathrm{P}$ and $\mathrm{K}$ ) as compared to control under heat stress (Vazirmehar and Rigi, 2014). Therefore, the present research aims to assess the effect of sowing at different thermal environments and foliar spray of bioregulators on productivity and nutritional composition of wheat under the era of climate change.

\section{Materials and Methods}

An experiment was carried out during rabi seasons of 2016-17 and 2017-18 at the Agronomy Farm of S.K.N. College of
Agriculture, Jobner situated at latitude of $26^{0}$ $05^{\prime}$ North, longitude of $75^{\circ} 28^{\prime}$ East and at an altitude of 427 metres above mean sea level. The site of the experiment is cold winter, hot and dry summer which is semi-arid type climate with $400 \mathrm{~mm}$ mean annual normal rainfall, of which $80 \%$ is received during July-September through south-west monsoon. The soil texture of the field was loamy sand with $8.25 \mathrm{pH}, 1.24 \mathrm{dS} / \mathrm{m}$ EC, $0.22 \%$ O.C. $130.3 \mathrm{~kg} / \mathrm{ha}$ available N (Subbiah and Asija, 1956), $15.2 \mathrm{~kg} / \mathrm{ha}$ available $\mathrm{P}$ (Olsen et al., 1954) and $149 \mathrm{~kg} / \mathrm{ha}$ available K (Jackson, 1973). Field experiment was conducted in four times replicated split plot design with 24 treatments, which consisting of three sowing at different thermal environments, viz. $\mathrm{D}_{1}(22$ $\left.{ }^{\circ} \mathrm{C}\right), \mathrm{D}_{2}\left(20{ }^{\circ} \mathrm{C}\right), \mathrm{D}_{3}\left(18{ }^{\circ} \mathrm{C}\right)$ and eight foliar spray of bio-regulators, viz. $\mathrm{B}_{1}$, control; $\mathrm{B}_{2}$, water spray; $\mathrm{B}_{3}$, salicylic acid @ 100 ppm; B,$\quad$ salicylic acid @ 200 ppm; $\mathrm{B}_{5}$, thiosalicylic acid @ 100 ppm; $\mathrm{B}_{6}$, thiosalicylic acid @ 200 ppm; B 7 , thioglycolic acid @ 100 ppm; and $\mathrm{B}_{8}$, thioglycolic acid @ 200 ppm. Bio-regulators were sprayed by using foot sprayer at tillering and ear emergence stages of crop growth.

The wheat cultivar 'Raj 3765' was sown during the experimentation, by pora method using $100 \mathrm{~kg} / \mathrm{ha}$ seed rate with the $22.5 \mathrm{~cm}$ row spacing. The recommended dose of $\mathrm{N}$ $(120 \mathrm{~kg} / \mathrm{ha})$ was applied in two splits, half dose before sowing and remaining half dose with first irrigation. The entire dose of phosphorus (40 $\mathrm{kg} \mathrm{P}_{2} \mathrm{O}_{5} / \mathrm{ha}$ ) was incorporated into the soil as basal just before sowing of the crop. Urea and DAP were broadcasted for nitrogen and phosphorus application. Six irrigations were given during entire life cycle of crop. Harvesting was done manually and after threshing, cleaning and drying, the grain and straw yields of wheat was calculated and expressed in $\mathrm{kg} / \mathrm{ha}$. According to recommendations, all other cultural practices were carried out. At the time of threshing, 
grain and straw samples were carried from each plot after proper drying and then grounding for estimation of nutrient content by standard methods.

\section{Results and Discussion}

\section{Effect of sowing at different thermal environments}

Yield and nutrient content in grain and straw varied significantly due to sowing at different thermal environments during both the years and in pooled mean. The significantly highest grain and straw yields of wheat were recorded under $\mathrm{D}_{2}$ with the respective values of 3771 and $4880 \mathrm{~kg} / \mathrm{ha}$. The minimum grain and straw yields were noted with $\mathrm{D}_{3}$ (3437 and $4533 \mathrm{~kg} / \mathrm{ha}$ ). The quantum increase in yield due to $\mathrm{D}_{2}$ (sowing at $20^{\circ} \mathrm{C}$ ) was 5.28 and 9.72 per cent in grain yield and 4.79 and 7.65 per cent in straw yield over $\mathrm{D}_{1}$ (sowing at $22{ }^{\circ} \mathrm{C}$ ) and $\mathrm{D}_{3}$ (sowing at $18{ }^{\circ} \mathrm{C}$ ), respectively. Changing the sowing time towards favourable environment created a significant effect on the crop yield, probably driven by the different thermal regimes prevailing throughout the grain filling period resulted into higher yield. The findings of Tripathi et al., (2013), Kumar et al., (2013) and Suleiman et al., (2014) are closely related to above results.

Sowing of wheat at $20{ }^{\circ} \mathrm{C}\left(\mathrm{D}_{2}\right)$ significantly increased the nutrient $(\mathrm{N}, \mathrm{P}$ and $\mathrm{K})$ content in grain and straw and being at par with sowing at $22{ }^{\circ} \mathrm{C}\left(\mathrm{D}_{1}\right)$ in respect to $\mathrm{P}$ content in straw proved superior over $\mathrm{D}_{1}$ and $\mathrm{D}_{3}$ treatments. The $\mathrm{N}, \mathrm{P}$ and $\mathrm{K}$ content in grain and straw have positive association with temperature prevailed during the crop growth period and on-time sowing. These findings were similar to those of Mukherjee (2012) and Mukherjee et al., (2017) (Table 1).

Table.1 Effect of sowing at different thermal environments and foliar spray of bio-regulators on grain and straw yields

\begin{tabular}{|c|c|c|c|c|c|c|}
\hline \multirow[t]{3}{*}{ Treatments } & \multicolumn{6}{|c|}{ Yield (kg/ha) } \\
\hline & \multicolumn{3}{|c|}{ Grain } & \multicolumn{3}{|c|}{ Straw } \\
\hline & 2016-17 & 2017-18 & Pooled & 2016-17 & 2017-18 & Pooled \\
\hline \multicolumn{7}{|c|}{ Sowing at different thermal environments } \\
\hline $\mathbf{D}_{1}$ & 3667 & 3498 & 3582 & 4742 & 4572 & 4657 \\
\hline $\mathbf{D}_{2}$ & 3860 & 3681 & 3771 & 4940 & 4820 & 4880 \\
\hline $\mathbf{D}_{3}$ & 3503 & 3372 & 3437 & 4623 & 4443 & 4533 \\
\hline SEm \pm & 55 & 55 & 39 & 62 & 47 & 39 \\
\hline $\mathrm{CD}(\mathrm{P}=\mathbf{0 . 0 5})$ & 189 & 191 & 120 & 213 & 163 & 119 \\
\hline \multicolumn{7}{|c|}{ Foliar spray of bio-regulators } \\
\hline $\mathbf{B}_{1}$ & 3258 & 3203 & 3230 & 4314 & 4195 & 4254 \\
\hline $\mathbf{B}_{2}$ & 3398 & 3318 & 3358 & 4470 & 4326 & 4398 \\
\hline $\mathbf{B}_{3}$ & 3538 & 3327 & 3432 & 4623 & 4312 & 4467 \\
\hline $\mathbf{B}_{4}$ & 3991 & 3758 & 3874 & 5045 & 4952 & 4998 \\
\hline $\mathbf{B}_{5}$ & 3701 & 3461 & 3581 & 4842 & 4564 & 4703 \\
\hline $\mathbf{B}_{6}$ & 3879 & 3701 & 3790 & 4944 & 4916 & 4930 \\
\hline $\mathbf{B}_{7}$ & 3724 & 3575 & 3649 & 4910 & 4697 & 4804 \\
\hline $\mathbf{B}_{8}$ & 3925 & 3792 & 3858 & 5000 & 4932 & 4966 \\
\hline SEm \pm & 87 & 67 & 55 & 94 & 87 & 64 \\
\hline $\mathrm{CD}(\mathrm{P}=0.05)$ & 245 & 189 & 153 & 265 & 247 & 180 \\
\hline \multicolumn{7}{|c|}{ Interaction (D x B) } \\
\hline SEm \pm & 150 & 116 & 95 & 163 & 151 & 111 \\
\hline $\mathrm{CD}(\mathrm{P}=0.05)$ & NS & NS & 265 & NS & NS & NS \\
\hline
\end{tabular}


Table. 2 Effect of sowing at different thermal environments and foliar spray of bio-regulators on nitrogen content in grain and straw

\begin{tabular}{|c|c|c|c|c|c|c|}
\hline \multirow[t]{3}{*}{ Treatments } & \multicolumn{6}{|c|}{ Nitrogen content (\%) } \\
\hline & \multicolumn{3}{|c|}{ Grain } & \multicolumn{3}{|c|}{ Straw } \\
\hline & 2016-17 & 2017-18 & Pooled & 2016-17 & 2017-18 & Pooled \\
\hline \multicolumn{7}{|c|}{ Sowing at different thermal environments } \\
\hline $\mathbf{D}_{1}$ & 1.65 & 1.53 & 1.59 & 0.581 & 0.559 & 0.570 \\
\hline $\mathbf{D}_{2}$ & 1.77 & 1.65 & 1.71 & 0.630 & 0.605 & 0.617 \\
\hline $\mathbf{D}_{3}$ & 1.59 & 1.52 & 1.56 & 0.536 & 0.515 & 0.525 \\
\hline SEm \pm & 0.04 & 0.03 & 0.02 & 0.02 & 0.02 & 0.011 \\
\hline CD $(P=0.05)$ & 0.13 & 0.11 & 0.07 & 0.06 & 0.06 & 0.035 \\
\hline \multicolumn{7}{|c|}{ Foliar spray of bio-regulators } \\
\hline $\mathbf{B}_{1}$ & 1.57 & 1.51 & 1.54 & 0.506 & 0.483 & 0.494 \\
\hline $\mathbf{B}_{2}$ & 1.60 & 1.53 & 1.56 & 0.544 & 0.523 & 0.534 \\
\hline $\mathbf{B}_{3}$ & 1.67 & 1.50 & 1.59 & 0.604 & 0.581 & 0.593 \\
\hline $\mathbf{B}_{4}$ & 1.86 & 1.75 & 1.80 & 0.655 & 0.623 & 0.639 \\
\hline $\mathbf{B}_{5}$ & 1.65 & 1.48 & 1.57 & 0.551 & 0.532 & 0.542 \\
\hline $\mathbf{B}_{6}$ & 1.65 & 1.55 & 1.60 & 0.596 & 0.576 & 0.586 \\
\hline $\mathbf{B}_{7}$ & 1.64 & 1.53 & 1.58 & 0.575 & 0.556 & 0.566 \\
\hline $\mathbf{B}_{8}$ & 1.73 & 1.70 & 1.71 & 0.626 & 0.603 & 0.615 \\
\hline SEm \pm & 0.05 & 0.05 & 0.03 & 0.03 & 0.03 & 0.019 \\
\hline $\mathrm{CD}(\mathrm{P}=0.05)$ & 0.13 & 0.14 & 0.09 & 0.07 & 0.07 & 0.052 \\
\hline \multicolumn{7}{|c|}{ Interaction (D x B) } \\
\hline SEm \pm & 0.08 & 0.09 & 0.06 & 0.05 & 0.05 & 0.03 \\
\hline CD $(P=0.05)$ & NS & NS & NS & NS & NS & NS \\
\hline
\end{tabular}

Table.3 Effect of sowing at different thermal environments and foliar spray of bio-regulators on phosphorus content in grain and straw

\begin{tabular}{|c|c|c|c|c|c|c|}
\hline \multirow[t]{3}{*}{ Treatments } & \multicolumn{6}{|c|}{ Phosphorus content (\%) } \\
\hline & \multicolumn{3}{|c|}{ Grain } & \multicolumn{3}{|c|}{ Straw } \\
\hline & 2016-17 & 2017-18 & Pooled & 2016-17 & 2017-18 & Pooled \\
\hline \multicolumn{7}{|c|}{ Sowing at different thermal environments } \\
\hline $\mathbf{D}_{1}$ & 0.479 & 0.455 & 0.467 & 0.165 & 0.161 & 0.163 \\
\hline $\mathbf{D}_{2}$ & 0.528 & 0.510 & 0.519 & 0.170 & 0.171 & 0.171 \\
\hline $\mathbf{D}_{3}$ & 0.437 & 0.413 & 0.425 & 0.154 & 0.153 & 0.153 \\
\hline SEm \pm & 0.015 & 0.016 & 0.011 & 0.004 & 0.005 & 0.003 \\
\hline $\mathrm{CD}(\mathbf{P}=\mathbf{0 . 0 5})$ & 0.052 & 0.054 & 0.034 & 0.012 & 0.014 & 0.012 \\
\hline \multicolumn{7}{|c|}{ Foliar spray of bio-regulators } \\
\hline $\mathbf{B}_{1}$ & 0.404 & 0.382 & 0.393 & 0.152 & 0.146 & 0.149 \\
\hline $\mathbf{B}_{2}$ & 0.442 & 0.417 & 0.430 & 0.154 & 0.155 & 0.155 \\
\hline $\mathbf{B}_{3}$ & 0.502 & 0.477 & 0.489 & 0.165 & 0.164 & 0.165 \\
\hline $\mathbf{B}_{4}$ & 0.553 & 0.534 & 0.543 & 0.174 & 0.171 & 0.173 \\
\hline $\mathbf{B}_{5}$ & 0.449 & 0.431 & 0.440 & 0.158 & 0.159 & 0.158 \\
\hline $\mathbf{B}_{6}$ & 0.503 & 0.475 & 0.489 & 0.169 & 0.168 & 0.168 \\
\hline $\mathbf{B}_{7}$ & 0.473 & 0.453 & 0.463 & 0.163 & 0.160 & 0.162 \\
\hline $\mathbf{B}_{8}$ & 0.524 & 0.505 & 0.515 & 0.169 & 0.170 & 0.170 \\
\hline SEm \pm & 0.022 & 0.024 & 0.016 & 0.005 & 0.006 & 0.005 \\
\hline $\mathrm{CD}(\mathrm{P}=0.05)$ & 0.062 & 0.068 & 0.045 & 0.015 & 0.017 & 0.015 \\
\hline \multicolumn{7}{|c|}{ Interaction (D x B) } \\
\hline SEm \pm & 0.04 & 0.04 & 0.03 & 0.009 & 0.014 & 0.008 \\
\hline CD $(P=0.05)$ & NS & NS & NS & NS & NS & NS \\
\hline
\end{tabular}


Table.4 Effect of sowing at different thermal environments and foliar spray of bio-regulators on potassium content in grain and straw

\begin{tabular}{|c|c|c|c|c|c|c|}
\hline \multirow[t]{3}{*}{ Treatments } & \multicolumn{6}{|c|}{ Potassium content $(\%)$} \\
\hline & \multicolumn{3}{|c|}{ Grain } & \multicolumn{3}{|c|}{ Straw } \\
\hline & 2016-17 & 2017-18 & Pooled & 2016-17 & 2017-18 & Pooled \\
\hline \multicolumn{7}{|c|}{ Sowing at different thermal environments } \\
\hline $\mathbf{D}_{1}$ & 0.446 & 0.427 & 0.437 & 1.621 & 1.502 & 1.562 \\
\hline $\mathbf{D}_{2}$ & 0.495 & 0.477 & 0.486 & 1.736 & 1.621 & 1.678 \\
\hline $\mathbf{D}_{3}$ & 0.401 & 0.381 & 0.391 & 1.565 & 1.492 & 1.529 \\
\hline SEm \pm & 0.017 & 0.016 & 0.012 & 0.036 & 0.031 & 0.024 \\
\hline $\mathrm{CD}(\mathrm{P}=\mathbf{0 . 0 5})$ & 0.057 & 0.056 & 0.036 & 0.125 & 0.109 & 0.074 \\
\hline \multicolumn{7}{|c|}{ Foliar spray of bio-regulators } \\
\hline $\mathbf{B}_{1}$ & 0.371 & 0.349 & 0.360 & 1.538 & 1.485 & 1.511 \\
\hline $\mathbf{B}_{2}$ & 0.409 & 0.389 & 0.399 & 1.565 & 1.495 & 1.530 \\
\hline $\mathbf{B}_{3}$ & 0.461 & 0.449 & 0.455 & 1.644 & 1.473 & 1.558 \\
\hline $\mathbf{B}_{4}$ & 0.520 & 0.501 & 0.510 & 1.832 & 1.717 & 1.775 \\
\hline $\mathbf{B}_{5}$ & 0.416 & 0.399 & 0.408 & 1.622 & 1.450 & 1.536 \\
\hline $\mathbf{B}_{6}$ & 0.469 & 0.448 & 0.458 & 1.617 & 1.523 & 1.570 \\
\hline $\mathbf{B}_{7}$ & 0.440 & 0.422 & 0.431 & 1.608 & 1.497 & 1.553 \\
\hline $\mathbf{B}_{8}$ & 0.491 & 0.467 & 0.479 & 1.698 & 1.668 & 1.683 \\
\hline SEm \pm & 0.026 & 0.027 & 0.019 & 0.046 & 0.050 & 0.034 \\
\hline $\mathrm{CD}(\mathrm{P}=0.05)$ & 0.074 & 0.075 & 0.052 & 0.129 & 0.140 & 0.094 \\
\hline \multicolumn{7}{|c|}{ Interaction (D x B) } \\
\hline SEm \pm & 0.05 & 0.05 & 0.03 & 0.079 & 0.086 & 0.058 \\
\hline CD $(P=0.05)$ & NS & NS & NS & NS & NS & NS \\
\hline
\end{tabular}

\section{Effect of foliar spray of bio-regulators}

Data further indicated that different foliar spray of bio-regulator treatments were significantly influence the yield and nutrient content in grain and straw during both the years and in pooled analysis. The significantly higher values of grain and straw yields (3874 and $4998 \mathrm{~kg} / \mathrm{ha}$ ) of wheat were observed under the application of salicylic acid @ 200 ppm over remaining treatments while it was at par with thiosalicylic acid and thioglycolic acid @ 200 ppm. The significantly minimum grain and straw yields were obtained under control with the corresponding values of 3230 and $4254 \mathrm{~kg} / \mathrm{ha}$. Foliar spray of salicylic acid @ 200 ppm $\left(\mathrm{B}_{4}\right)$ represented an increase in yield to the tune of 19.94 and 15.37 per cent in grain yield and 17.49 and 13.64 per cent in straw yield, respectively over $\mathrm{B}_{1}$ (control) and $\mathrm{B}_{2}$ (water spray). The period of photo synthetically active sites in crop plants are extended in response to exogenous application of bio-regulators towards higher biomass accumulation increase in the crop yield, consequently delayed senescence of plant organs (particularly leaves and flowers). These findings are in agreement with Kumawat et al., (2013) Sharma et al., (2013) and Nathawat et al., (2016).

Among foliar spray of bio-regulator treatments, SA @ 200 ppm $\left(\mathrm{B}_{4}\right)$ recorded the significantly higher nitrogen and phosphorus content in grain and straw which was at par with $B_{8}$ in respect of grain and with $B_{3}$ and $B_{8}$ in respect of straw. While with regard to $\mathrm{P}$ content in straw, the above treatment also remained at par with $\mathrm{B}_{5}, \mathrm{~B}_{6}$ and $\mathrm{B}_{7}$. Application of SA @ 200 ppm $\quad\left(B_{4}\right)$ significantly increased $\mathrm{K}$ content in grain and straw over other treatments but remained at par with $\mathrm{B}_{6}$ and $\mathrm{B}_{8}$. Since, content of nutrients is the function of grain and straw yield hence, a clear involvement of bio-regulators in the control of nutrient assimilation might be 
expected. These results are in line with those of Muhal et al., (2014) and Premaradhya et al., (2018) (Table 2-4).

\section{Interaction effect}

Data represented that collective effect between sowing at different thermal environments and foliar spray of bioregulators was found to be non-significant with regard to straw yield and nutrient content of wheat. While, interaction effect of sowing at different thermal environments and foliar spray of bio-regulator treatments on grain yield of wheat was found to be significant.

Based on the study, it was concluded that highest productivity and nutrient content in grain and straw were obtained with the application of salicylic acid @ 200 ppm at tillering and ear emergence stages of wheat along with sowing at $20{ }^{\circ} \mathrm{C}$ mean temperature.

\section{References}

Agarwal, V.P., Gupta, N.K., Gupta, P.C., Rizwan, M. and Singh, G. 2017. Sulfhydryl compounds mitigate the adverse effect of high temperature stress in contrasting wheat genotypes. Vegetos, 30, 1.

Anonymous, 2020a. Progress report All India Coordinated Wheat and Barley Improvement Project. Directorate of wheat research, Karnal, 14.

Anonymous, 2020b. Rajasthan Agriculture Statistics At A Glance. Comissionarate of Agriculture Rajasthan, 60-61.

Jackson, M.L. 1973. Soil Chemical Analysis. Prentice Hall of India Pvt. Ltd., New Delhi.

Khan, M.B., Ghurchani, M., Hussain, M. and Mahmood, K. 2010. Wheat seed invigoration by pre-sowing chilling treatments. Pakistan Journal of Botany, 42:1561-1566.
Khan, S., Memon, A.N., Deverajani, B.R. and Baloch, S. 2015. Physicochemical characteristics of wheat grain and their relation with proteins in different varieties cultivated in Sindh. Sindh University Research Journal, 47(4): 839-842.

Kumawat, A., Jakhar, R.K., Prasad, M. and Rathore, P.S. 2013. Performance of barley under the influence of bioregulators under different potassium levels. Bioinfolet 10 (1B): 204-208.

Lal, R. 2013. Food security in a changing climate. Ecohydrol. and Hydrobio 13:1, (Sp. Iss) SI, 8-21.

Meena, H., Meena, R.S., Lal, R., Yadav, G.S., Mitran, T., Layek, J., Patil, S.B., Kumar, S. and Verma, T. 2017. Response of sowing dates and bio regulators on yield of clusterbean under current climate in alley cropping system in eastern U.P., India. Legume Research, 3759, 1-9, ISSN:0250-5371.

Meena, V.K., Kaushik, M.K., Kumar, R.K., Singh, M., Meena B.P., Meena, B.L., Meena, R.K., Kumar, U. and Kumar, S. 2016. Influence of growth regulators on nutrient concentrations, nutrient uptake and quality parameters of cluster bean varieties. Leg. Res. 39(5): 797-801.

Muhal, S., Solanki, N.S., Singh, P. and Shukla, K.B. 2014. Effect of salicylic acid on productivity and nutrient uptake of Brassica species under different planting duration. African Journal of Agricultural Research, 9: 1101-1106.

Mukherjee, D. 2012. Effect of different sowing dates on growth and yield of wheat (Triticum aestivum) cultivars under mid hill situation of West Bengal. Indian Journal of Agronomy, 57 (2): 152-156.

Mukherjee, D., Mandal, B., Maji, A. and Biswas, B. 2017. Impact of various 
planting dates and suitable nutrient management practices for enhanced wheat (Triticum aestivum L.) productivity. International Journal of Bioresource Science, 4(1): 29-34.

Nathawat, N.S., Rathore, V.S., Meel, B., Bhardwaj, S. and Yadava, N.D. 2016. Enhancing Yield Of Clusterbean (Cyamopsis tetragonoloba L. Taub) With Foliar Application of Sulphydryl Compounds Under Hot Arid Conditions. Experimental Agriculture, 52(3): 418-433.

Olsen, S.R., Cole, C.W., Watanabe, F.S. and Dean, L.A. 1954. Estimation of available phosphorus in soils by extraction with $\mathrm{NaHCO}_{3}$, USDA Circular no. 939, Washington.

Premaradhya, N., Shashidhar, K.S., Jeberson, S., Krishnappa, R. and Singh, N. 2018. Effect and profitability of foliar application of thiourea on growth and yield attributes of lentil (Lens culinaris L.) under Manipur Conditions of North-East, India. International Journal of Current Microbiology and Applied Sciences, 7(5): 1040-1050.

Sattar, A., Cheema, M.A., Farooq, M., Wahid, M.A., Wahid, A. and Babar, B.H. 2010. Evaluating the performance of wheat cultivars under late sown conditions. International Journal of Agriculture and Biology, 12:561-565.

Sharma, P., Sardana, V. and Banga, S.S. 2013. Effect of salicylic acid on growth and seed filling in Indian mustard (Brassica juncea L. Czern \&
Coss) under high temperature stress. International Journal of Plant Research, 26: 243-248.

Shivran, A, Patel, B.J. and Gora, M. 2019. Effect of irrigation schedule and bioregulators on yield attributes and yield of mustard $[B$. juncea (L.) Czern\&Coss] crop. Intl $J$ Chem Studies, 7:1874-1877.

Singh, A. and Meena, R.S. 2020 Response of bioregulators and irrigation on plant height of Indian mustard (Brassica juncea L.). Journal of Oilseed Brassica, 11(1): 9-14.

Subbiah, B.V. and Asija, G.L. 1956. A rapid procedure for estimation of available nitrogen in soils. Current Science, 25: 259-260.

Suleiman, A.A., Nganya, J.F. and Ashraf, M.A. 2014. Effect of cultivar and sowing date on growth and yield of Wheat (Triticum aestivum L.) in Khartoum, Sudan. Journal of Forest Products and Industries, 3(4):198-203.

Tripathi, S.C., Chander, S. and Meena, R.P. 2013. Effect of early sowing, N levels and seed rates on yield and yield attributes of different wheat (Triticum aestivum) varieties. Indian Journal of Agronomy, 58(1): 63 -66.

Vazirmehr, M.R. and Rigi, K. 2014. Effect of salicylic acid in agriculture. International Journal of Plant, Animal and Environmental Sciences, 4(2): 291-296.

\section{How to cite this article:}

Hansa Lakhran, O.P. Sharma, Rohitash Bajiya and Meena Choudhary. 2020. Productivity and Nutrient Content of Wheat (Triticum aestivum L.) as Influenced by Sowing Temperatures and Bio-regulators. Int.J.Curr.Microbiol.App.Sci. 9(10): 2609-2615. doi: https://doi.org/10.20546/ijcmas.2020.910.314 